\title{
Effects of a luteolytic dose of oestradiol benzoate on uterine oxytocin receptor concentrations, phosphoinositide turnover and prostaglandin F-2 $\alpha$ secretion in sheep*
}

\author{
J. E. Hixon $\dagger$ and A. P. F. Flint \\ A.F.R.C. Institute of Animal Physiology and Genetics Research, Babraham, Cambridge CB2 4AT, \\ U.K.
}

\begin{abstract}
Summary. Administration of oestradiol-17 $\beta$ benzoate on Days 9 and 10 of the oestrous cycle resulted in episodic secretion of PGF- $2 \alpha$ (as indicated by elevated circulating concentrations of 13,14-dihydro-15-ketoprostaglandin F-2 $\alpha$ ) and a decline in circulating progesterone. Release of PGF $-2 \alpha$ began $35 \pm 3 \mathrm{~h}$ after first injection of oestrogen and progesterone concentrations declined from $42 \pm 3 \mathrm{~h}$. Secretion of oxytocin, which was first observed $26 \pm 3 \mathrm{~h}$ after oestrogen treatment, preceded secretion of PGF- $2 \alpha ; 69 \%$ of pulses of oxytocin coincided with episodes of PGF-2 $\alpha$ secretion.

Uterine oxytocin receptor concentrations were raised in ewes treated with oestrogen, increases occurring in caruncular endometrium and myometrium by $12 \mathrm{~h}$ after treatment and in intercaruncular endometrium by $24 \mathrm{~h}$. Raised receptor concentrations were followed at $24 \mathrm{~h}$ by increases in the incorporation of $\left[{ }^{3} \mathrm{H}\right]$ inositol into phosphatidylinositol and in the hydrolysis of labelled tissue phosphoinositides in response to oxytocin in slices of caruncular endometrium incubated in vitro. The following sequence of events is therefore suggested to occur at oestrogen-induced luteolysis: (a) induction of the oxytocin receptor; (b) increased turnover of phosphoinositides; (c) onset of episodic secretion of PGF-2 $\alpha$; and (d) functional luteolysis.
\end{abstract}

\section{Introduction}

Uterine concentrations of the oxytocin receptor rise at luteolysis in sheep (Roberts et al., 1976), but despite simultaneous measurements of circulating progesterone and the receptor it has not been possible to determine whether the rise in receptor precedes or follows luteal regression (Sheldrick \& Flint, 1985). It is not known therefore whether induction of the oxytocin receptor causes the fall in circulating progesterone concentration at luteolysis or results from it. Evidence that it may play a causative role includes the fact that uterine secretion of prostaglandin (PG) F- $2 \alpha$, the luteolysin, is stimulated by oxytocin (Sharma \& Fitzpatrick, 1974; Mitchell et al., 1975), presumably through interaction with the oxytocin receptor.

Oestradiol-17 $\beta$ given during the mid-luteal phase of the oestrous cycle causes luteolysis in sheep and cattle (Brunner et al., 1969; Bolt \& Hawk, 1975; Hansel \& Convey, 1983) and in rats and rabbits the oxytocin receptor is induced in uterine tissues after administration of oestradiol-17 $\beta$ (Soloff, 1975; Nissenson et al., 1978). It is possible therefore that the luteolytic effect of oestradiol-17 $\beta$ may be mediated through induction of the oxytocin receptor. The present experiments were undertaken to determine whether oestradiol-induced luteolysis is associated with raised

\footnotetext{
*Reprint requests to Dr A. P. F. Flint.

†Permanent address: Department of Veterinary Biosciences, University of Illinois, 2001 S. Lincoln Ave., Urbana, Illinois 6180I, U.S.A.
} 
levels of the oxytocin receptor in sheep, and whether any such rise precedes or follows luteal regression and the fall in circulating progesterone. It was anticipated that the data obtained would improve our understanding both of the mechanism of the luteolytic effect of oestrogen and of the role of the oxytocin receptor in spontaneous luteolysis. Uterine phosphatidylinositol cycle activity was determined because its activation by oxytocin has been postulated to represent a source of arachidonic acid for synthesis of PGF-2 $\alpha$ (Flint et al., 1986).

\section{Materials and Methods}

Animals. Clun Forest ewes kept in a paddock were examined daily for oestrous behaviour; all 31 ewes cycled spontaneously, and each animal had exhibited at least 2 oestrous cycles with a mean $( \pm$ s.e.m.) length of $16 \cdot 6 \pm 0 \cdot 2$ days before experimentation.

The animals were allocated at random to 2 experiments. Experiment 1 was designed to determine the time course of changes in progesterone, 13,14-dihydro-15-keto-PGF-2 $\alpha$ (DHKF-2 $\alpha$ ) and oxytocin after administration of oestrogen. Ewes were treated with $750 \mu \mathrm{g}$ oestradiol- $17 \beta$ benzoate $(\mathrm{N}=5)$ at $12: 00 \mathrm{~h}$ on Days 9 and 10 after oestrus (day of oestrus = Day 0 ) or with arachis oil $(\mathrm{N}=5)$, which was the vehicle for oestradiol benzoate. Blood samples were collected for measurement of progesterone, oxytocin and DHKF- $2 \alpha$ at $1 \cdot 5-\mathrm{h}$ intervals beginning $3 \mathrm{~h}$ before treatment on Day 9 and continuing until $72 \mathrm{~h}$ after the first injection. Concentrations of progesterone were also determined in plasma from blood samples collected 84 and $96 \mathrm{~h}$ after first administration of oestrogen or vehicle.

For frequent removal of blood samples, a polyvinylchloride catheter, o.d. $2.1 \mathrm{~mm}$, was inserted into an external jugular vein under local anaesthesia by the method of Seldinger (1953). Catheters were inserted at least $24 \mathrm{~h}$ before starting to collect blood samples. Immediately after catheterization, and during sampling, the ewes were kept in metabolism cages under conditions that allowed blood to be obtained without disturbing the animals (Flint \& Sheldrick, 1983). The ewes were removed from the cages daily (usually between 12:15 and 13:00 h) for testing for oestrous behaviour with a vasectomized ram, which was housed in the same room as the ewes.

In Exp. 2, cyclic ewes were killed at intervals after administration of $750 \mu \mathrm{g}$ oestradiol benzoate (given as in Exp. 1) for preparation of uterine oxytocin receptor and measurement of phosphatidylinositol turnover. Twelve animals were killed at $12,24,36$ or $48 \mathrm{~h}$ after the initial oestradiol treatment ( 3 at each time) and 9 vehicle-treated ewes were killed at 12:00 h on Days 9, 10 and 11 ( 3 on each day). To ensure that patterns of secretion after treatment were comparable to those observed in Exp. 1, all animals in Exp. 2 were sampled at $1.5 \mathrm{~h}$ intervals during the $12 \mathrm{~h}$ preceding slaughter, using the catheterization and blood sampling protocol described under Exp. 1 .

To obtain uteri, the animals were killed by intravenous administration of a lethal dose of pentobarbitone sodium; tissues were collected onto ice and were dissected immediately.

Determination of uterine oxytocin receptor concentrations. Membrane fractions were prepared from caruncular and intercaruncular endometrium and from myometrium by homogenization in $25 \mathrm{mM}-\mathrm{Tris}-\mathrm{HCl}, \mathrm{pH} 7.6$ containing $0.25 \mathrm{M}$-sucrose and $1 \mathrm{~mm}$-EDTA followed by differential centrifugation as described by Sheldrick \& Flint (1985). Extracts were stored at $-70^{\circ} \mathrm{C}$ until assay.

Oxytocin receptor concentrations were determined by incubating membrane fractions (10-54 $\mu$ g protein; mean \pm s.e.m., $35 \cdot 2 \pm 1 \cdot 2 \mu \mathrm{g}$ ) with $5 \mathrm{~nm} \cdot\left[3,5-{ }^{3} \mathrm{H}-\mathrm{Tyr}\right] \mathrm{xyytocin}$ (sp. act. $36 \cdot 6 \mathrm{Ci} / \mathrm{mmol}$; New England Nuclear Corp., Nuclear Research Products, Stevenage, Herts) for $15 \mathrm{~min}$ at $25^{\circ} \mathrm{C}$ in the presence of $1 \mathrm{mM}-\mathrm{MnCl}_{2}$. Separation of bound and free $\left[{ }^{3} \mathrm{H}\right]$ oxytocin was carried out by filtration through Millipore (Durapore, Type GVWP) filters (Sheldrick \& Flint, 1985). With reverse-phase high-performance liquid chromatography to confirm the purity of the tracer, $>90 \%$ of labelled material migrated with authentic oxytocin. As receptor binding was determined at one (saturating) ligand concentration only, no information was obtained on receptor affinity.

Measurement of incorporation of $~_{3}^{3} \mathrm{H}$ Jinositol into phosphatidylinositol. Individual endometrial caruncles dissected from the uterus with scissors were collected into ice-cold $0.9 \%(\mathrm{w} / \mathrm{v}) \mathrm{NaCl}$. Slices $(\sim 0.3 \mathrm{~mm}$ thick $)$ cut by hand using a razor blade were transferred to ice-cold Krebs-Ringer-bicarbonate-buffered saline (Krebs \& Henseleit, 1932) containing $10 \mathrm{~mm}$-glucose (Buffer 1). After blotting and weighing, a number of slices $(\sim 100 \mathrm{mg})$ were transferred to glass scintillation vials and incubated in $1 \mathrm{ml}$ Buffer 1 containing $10 \mu \mathrm{M}-m y o-\left[2-{ }^{3} \mathrm{H}\right]$ inositol $(1 \mu \mathrm{Ci} / \mathrm{ml}$; Amersham International, Amersham, Bucks; diluted as required with unlabelled myo-inositol; Sigma Chemical Co., Poole, Dorset) with or without $10^{-7} \mathrm{M}$-oxytocin (Bachem, Torrance, CA, U.S.A.) at $37^{\circ} \mathrm{C}$ for $2 \mathrm{~h}$. The vials were thoroughly gassed with $\mathrm{O}_{2}: \mathrm{CO}_{2}(95: 5 \mathrm{v} / \mathrm{v})$ and closed with a gas-tight stopper. Incubations were ended by removing the medium and homogenizing the slices in $10 \mathrm{ml}$ unacidified chloroform-methanol $(2: 1, \mathrm{v} / \mathrm{v})$. After separating the methanolic and chloroform phases by addition of $2 \mathrm{M}-\mathrm{NaCl}$, and subsequently washing the chloroform extract 4 times with $2 \mathrm{M}-\mathrm{NaCl}$, the radioactivity incorporated into phosphatidylinositol was counted and expressed as d.p.m./g wet wt of slices (Flint et al., 1986). All incubations were in triplicate.

Measurement of hydrolysis of phosphatidylinositol phosphates. Slices of caruncular endometrium were prepared and incubated as above in Buffer 1 containing $10 \mu \mathrm{M}-m y o-\left[2-{ }^{3} \mathrm{H}\right]$ inositol $(10 \mu \mathrm{Ci} / \mathrm{ml})$ without oxytocin. After incubation for $2 \mathrm{~h}$ the medium was replaced with $2 \mathrm{ml}$ Buffer 1 containing $10 \mathrm{~mm}$-unlabelled inositol, and the slices incubated for a further $30 \mathrm{~min}$. This medium was then removed and replaced with $1 \mathrm{ml}$ Buffer 1 containing $10 \mathrm{~mm}-\mathrm{LiCl}$; after 
incubation for a further $10 \mathrm{~min} 10^{-7} \mathrm{M}$-oxytocin was added, when appropriate, in $10 \mu \mathrm{l}$ Buffer 1 . Incubations were subsequently ended $20 \mathrm{~min}$ later by adding $1 \mathrm{ml}$ ice-cold $15 \%(\mathrm{w} / \mathrm{v})$ trichloroacetic acid.

After keeping on ice for $15 \mathrm{~min}$, slices were removed by centrifugation, supernatants were decanted and trichloroacetic acid was removed by extraction 5 times with $5 \mathrm{ml}$ water-saturated diethyl ether. Residual ether was removed under a stream of nitrogen at $40^{\circ} \mathrm{C}$ and the extracts were neutralized (to $\mathrm{pH} 7.0-8.5$ ) by adding $0.5 \mathrm{M}-\mathrm{NaOH}$ in $0.5 \mathrm{M}$-Tris before storage at $-20^{\circ} \mathrm{C}$.

$\left[{ }^{3} \mathrm{H}\right]$ Inositol and $\left[{ }^{3} \mathrm{H}\right]$ inositol mono-, bis- and trisphosphates were separated by using columns of Dowex-1 formate eluted sequentially with solutions of increasing ionic strength (Richards et al., 1979; Downes \& Michell, 1981), and results were expressed as d.p.m./g wet wt of slices incubated. All incubations were performed in triplicate. Further details of the procedure are given by Flint et al. (1986).

Radioimmunoassays. Progesterone was measured in plasma samples after extraction with diethyl ether as described by Sheldrick et al. (1980). Sensitivity of the assays reported here (calculated from $2 \times$ s.d. below the zero mass-added point) was equivalent to $0.12 \mathrm{ng} / \mathrm{ml}$ plasma. Intra- and inter-assay coefficients of variation were 7.4 and $9 \cdot 1 \%$ respectively, and mean extraction recovery was $85 \cdot 6 \pm 2 \cdot 3 \%$.

Oxytocin concentrations were determined after extraction with activated glass powder as validated by Sheldrick \& Flint (1981), using antiserum GJ137 (Sheldrick \& Flint, 1985). Extraction recoveries of ${ }^{125}$ I-labelled oxytocin added to plasma samples were $79.6 \pm 1.5 \%$, and sensitivity of the assay was $0.625 \mathrm{pg} / \mathrm{ml}$ plasma. Intra- and inter-assay coefficients of variation were $9 \cdot 2$ and $14.9 \%$ respectively.

DHKF-2 $\alpha$ was measured as described by Mitchell et al. (1975) after extracting acidified plasma with diethyl ether. Extraction recoveries were $82 \cdot 9 \pm 3 \cdot 2 \%$; assay sensitivity was equivalent to $60 \mathrm{pg} / \mathrm{ml} \mathrm{plasma} \mathrm{and} \mathrm{intra-and} \mathrm{inter-assay}$ coefficients of variation were 7.9 and $10.0 \%$ respectively.

Values were corrected for extraction losses in all cases. All samples were assayed in duplicate.

Statistics. Differences in progesterone between the groups of animals in Exp. 1 were assessed using a linear model that permitted calculation of statistical probabilities of (a) effects due to oestrogen treatment, (b) effects arising as a result of differences between individual animals in each group, (c) changes with time and (d) the interaction between oestrogen treatment and time. Changes with time and the interaction between treatment and time were not independent variables, because repeated measurements were made on the same ewes, and effects of these parameters were therefore tested using a conservative F-test (Gill, 1978). The time at which concentrations of progesterone began to decline in oestrogen-treated animals was estimated by fitting linear and quadratic regression curves to segments of the data for each animal (Lerman, 1980).

Statistically significant peaks in secretion of DHKF-2 $\alpha$ and oxytocin were identified using algorithms which assessed elevations of short duration in a series of observations by performing the following steps: (a) a base line was calculated representing the contribution of circadian rhythms or other long-term trends but not fluctuations of shorter duration; (b) a residual series that contained the secretory episodes, but not long-term trends, was calculated by subtracting base-line values; (c) the residual series was rescaled in terms of standard deviation units by dividing the rescaled values by an estimate of assay noise; (d) the peaks in the rescaled series were then identified by applying criteria of height and duration specified by user-defined cut-off points $(G(n))$. Peaks were thus identified as an individual subseries if they were elevated by $G(n)$ standard deviation units (where values of $G$ were selected by the user) for peaks of 1-5 datum points (n) in duration. (e) Steps (a)-(d) were repeated until 2 iterations produced the same values for peaks or until the preset limit, 6 iterations, was completed. Assay noise was estimated as a quadratic function of the quantity of hormone measured at each point (Merriam \& Wachter, 1982). By using duplicate values for each sample the mean and standard deviation were calculated; the entire series of standard deviations was plotted against the corresponding means and a quadratic model was fitted to relate the 2 parameters. Points in the series where hormone concentrations were below the lower limit of sensitivity of the assay were excluded from this calculation. The numerical values for the quadratic (a), linear (b) and constant (c) terms of the model were: for DHKF- $\alpha$, $a=0.00, b=0.11$ and $c=-0.42$; for oxytocin, $a=0.00, b=0.08$ and $c=0.22$. The $G(n)$ values were selected by an empirical approach using calibration data sets for each hormone. The following $G(n)$ values were derived for both oxytocin and DHKF-2 $\alpha: G(1)=4 \cdot 2, G(2)=2 \cdot 4, G(3)=1 \cdot 6, G(4)=1 \cdot 0$ and $G(5)=1 \cdot 0$. These calculations were carried out using a computer program, 'Pulsar' (Merriam et al., 1983).

In Exp. 2, the effects of oestrogen on oxytocin receptor and hormone concentrations in the groups killed at 24 and $48 \mathrm{~h}$ (Table 1) were analysed by Student's $t$ test. Variables in the oestrogen-treated groups killed at $12 \mathrm{or} 36 \mathrm{~h}$ were compared to mean values for the control groups killed at 0 and $24 \mathrm{~h}$ or 24 and $48 \mathrm{~h}$ respectively. Effects of oestrogen and oxytocin on incorporation of labelled inositol into phosphoinositides (Table 2) were analysed by multivariate analysis of variance after logarithmic transformation. Both original and transformed data are presented.

\section{Results}

Experiment 1: effects of oestradiol-17ß benzoate on luteal function and the secretion of PGF-2a and oxytocin

As expected from previous experience with the treatment used in this study (Hixon et al., 1975), premature luteolysis occurred after administration of oestrogen. Circulating concentrations of 
progesterone declined $(P<0.01)$ in all treated animals (Fig. 1); this decline began $42.0 \pm 3.0 \mathrm{~h}$ after oestrogen treatment on Day 9. Progesterone levels were unchanged in control animals (Fig. 2f); concentrations of progesterone in this group at 84 and $96 \mathrm{~h}$ after treatment were $2.87 \pm 0.42$ and $2.71 \pm 0.17 \mathrm{ng} / \mathrm{ml}$ respectively, compared to $0.37 \pm 0.14$ and $0.45 \pm 0.19 \mathrm{ng} / \mathrm{ml}$ respectively in ewes receiving oestrogen. Oestrus was observed $67 \pm 9 \mathrm{~h}$ after first administration of oestrogen; in control animals the interval from vehicle treatment to oestrus was $187 \pm 9 \mathrm{~h}(P<0 \cdot 01)$.
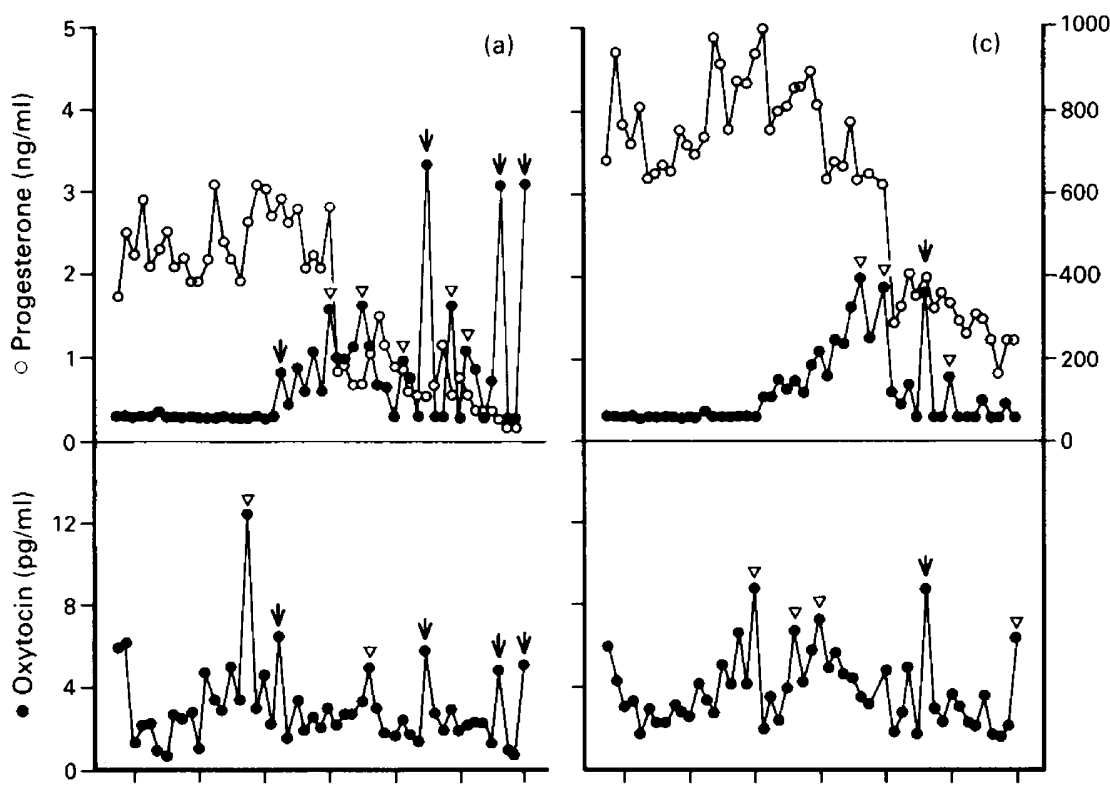

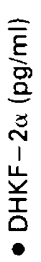
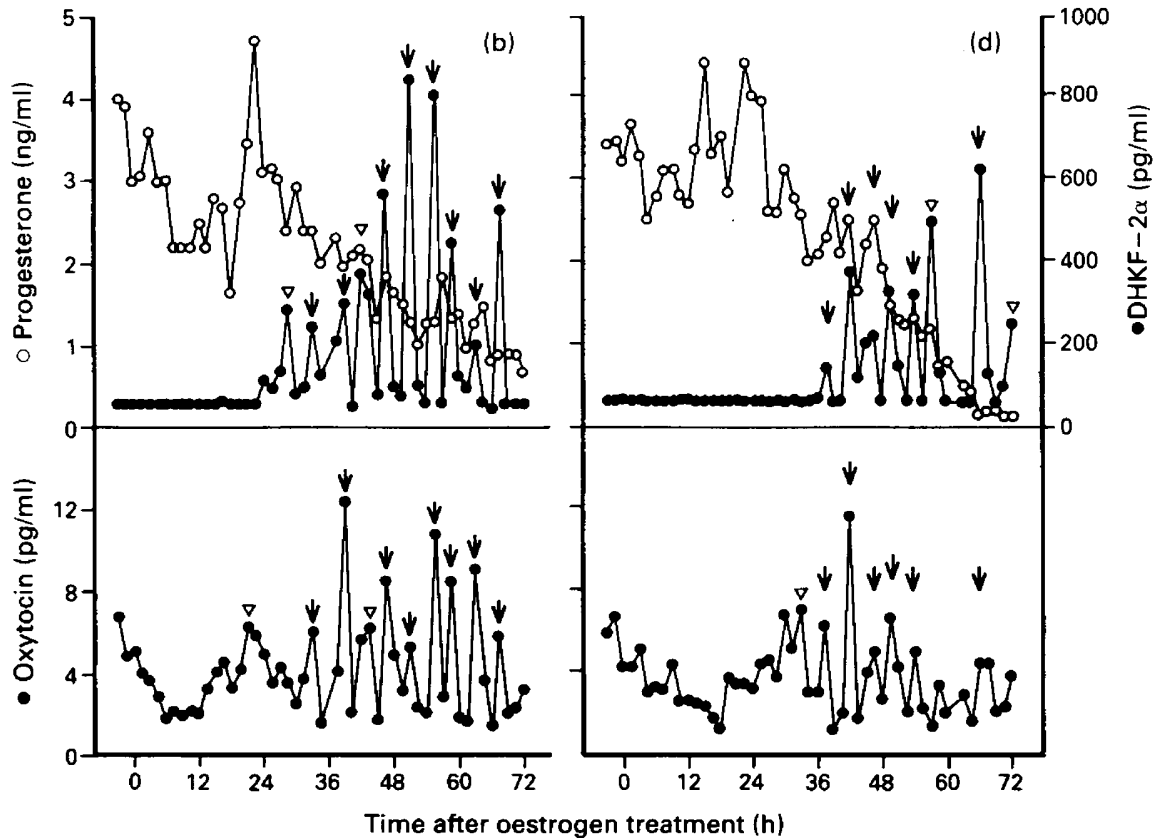

Fig. 1. 


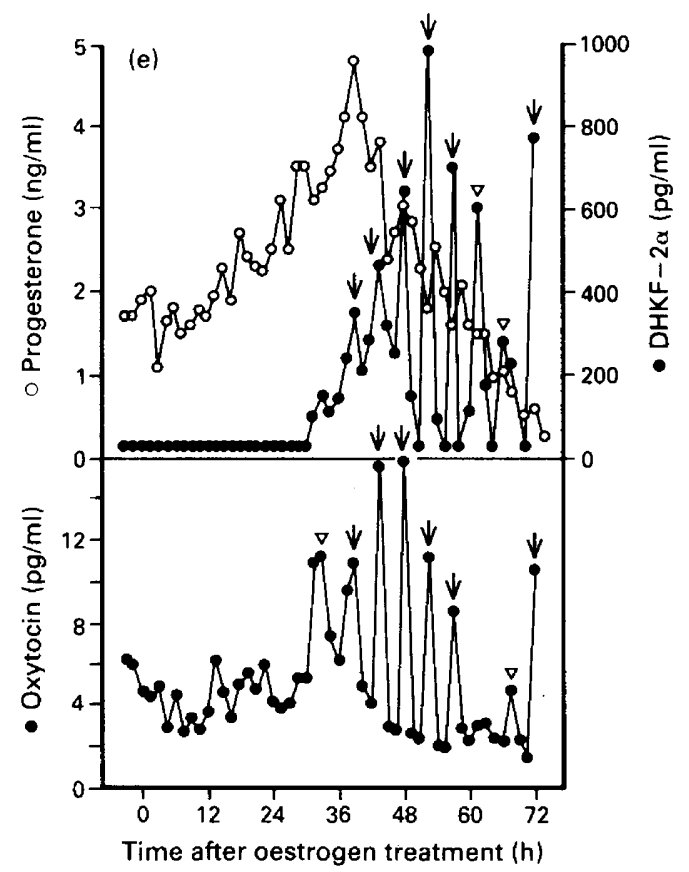

Fig. 1. Concentrations of progesterone, 13,14-dihydro-15-keto-prostaglandin F-2 $\alpha$ (DHKF-2 $\alpha$ ) and oxytocin in jugular venous plasma from individual ewes (a-e) treated with oestradiol-17 $\beta$ benzoate at $12: 00 \mathrm{~h}$ on Days 9 and 10 of the oestrous cycle. Zero time $(0 \mathrm{~h})$ represents $12: 00 \mathrm{~h}$ on Day 9. Statistically significant episodes of secretion of DHKF-2 $\alpha$ and oxytocin are indicated by arrows and inverted triangles; arrows identify synchronous episodes in both compounds, triangles indicate episodes in one compound only.

Episodes of secretion of DHKF-2 $\alpha$ were observed in ewes that received oestrogen (Fig. 1), the first peak occurring an average of $35 \pm 3 \mathrm{~h}$ after injection of oestrogen on Day 9 . The mean number of peaks observed/ewe was $8 \pm 1$ and the mean interval between peaks was $4 \cdot 9 \pm 0 \cdot 2 \mathrm{~h}$. There were no episodes of release of DHKF-2 $\alpha$ in control ewes (Fig. $2 \mathrm{~g}$ ) although concentrations of DHKF-2 $\alpha$ occasionally exceeded the lower limit of sensitivity of the assay.

Peaks in the secretion of oxytocin were observed in all ewes receiving oestrogen (Fig. 1) and in 3 of the 5 vehicle-treated ewes (Figs $2 \mathrm{a}, \mathrm{b} \& \mathrm{c}$ ). The interval of $26 \pm 3 \mathrm{~h}$ between the start of oestrogen treatment and the first peak in oxytocin was similar $(P>0 \cdot 10)$ to that $(29 \pm 9 \mathrm{~h})$ for the 3 vehicletreated ewes in which at least one episode of oxytocin secretion was observed. Because more episodes of oxytocin secretion were observed during the sampling period in ewes treated with oestrogen than in the vehicle-treated animals $(7 \pm 1$ vs $3 \pm 1 ; P<0.01)$, the interval between peaks was shorter in the former group $(7 \pm 1$ vs $11 \pm 2 \mathrm{~h} ; P<0.05)$. The mean amplitude (increment above baseline) for peaks of oxytocin was $5.50 \pm 0.49 \mathrm{pg} / \mathrm{ml}$ in oestrogen-treated ewes and $4.87 \pm$ $0.98 \mathrm{pg} / \mathrm{ml}$ in controls $(P>0 \cdot 10)$. The first episode of oxytocin secretion after start of oestrogen treatment preceded $(P<0.05)$ the first peak in DHKF- $2 \alpha$ secretion (Fig. 1). However, the average number of peaks/ewe for oxytocin $(7 \pm 1)$ and DHKF- $2 \alpha(8 \pm 1)$ did not differ significantly and 25 of the 36 oxytocin peaks observed were coincident with peaks in the secretion of DHKF-2 $\alpha$.

Experiment 2: effects of oestradiol benzoate on concentrations of progesterone, $D H K F-2 \alpha$ and oxytocin receptor and on synthesis and hydrolysis of phosphoinositides in response to oxytocin

Mean concentrations of progesterone during 12-h windows preceding the collection of uterine tissue at 12,24 and $36 \mathrm{~h}$ after oestrogen treatment were similar $(P>0 \cdot 10)$ to those in animals given 


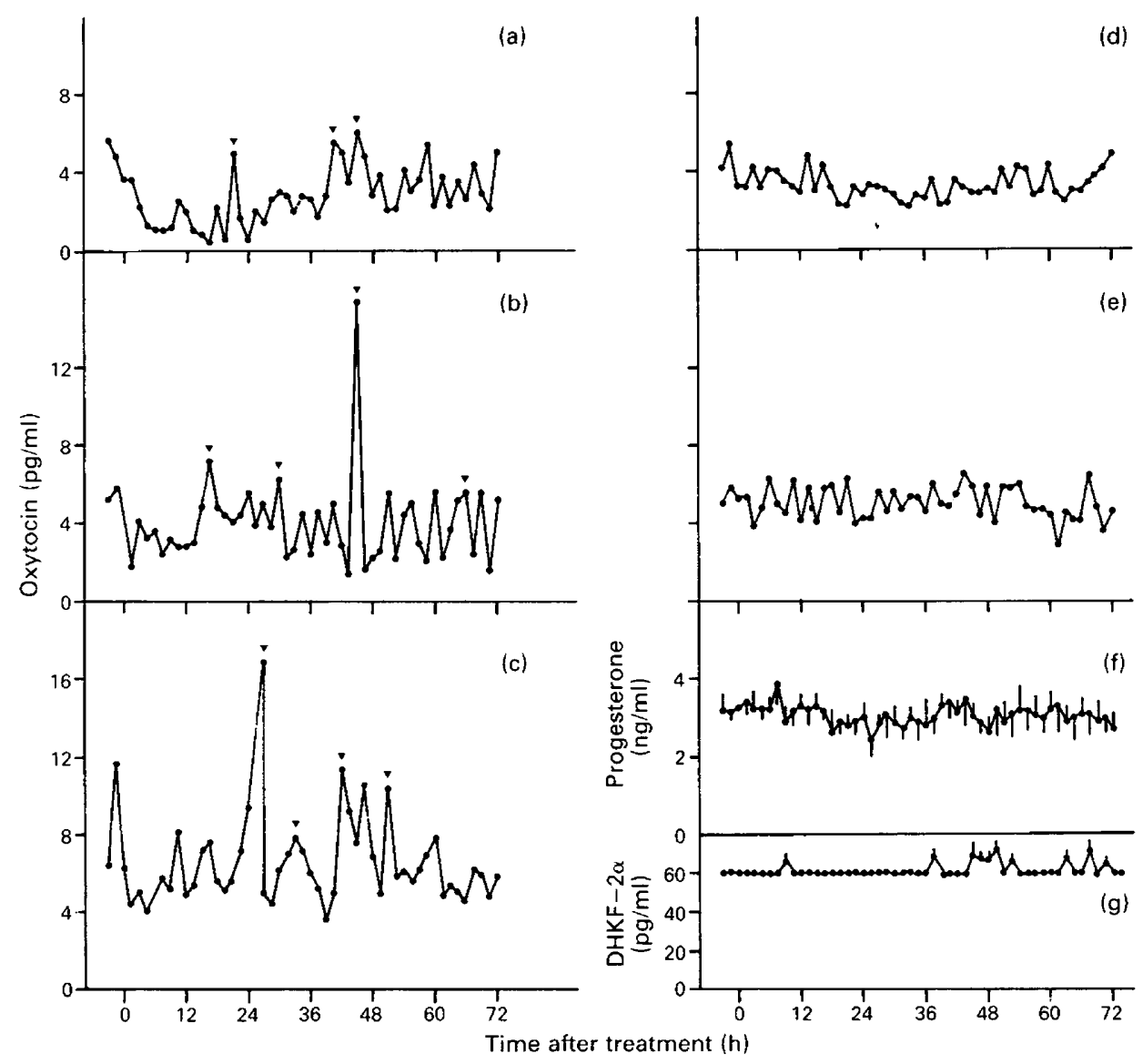

(d)

(e)

Fig. 2. Circulating concentrations of oxytocin (a-e), progesterone (f) and DHKF- $2 \alpha(\mathrm{g})$ in control animals receiving arachis oil at 12:00 h on Days 9 and 10. All hormones were measured in jugular venous plasma. Values for oxytocin are shown separately for each of the control ewes in Exp. 1, as patterns of pulsatile secretion differed between animals. Statistically significant episodes of secretion of oxytocin are indicated by $\boldsymbol{\nabla}$.

arachis oil. However, oestrogen treatment resulted in a lower mean concentration of progesterone preceding slaughter at $48 \mathrm{~h}$ than was observed between 36 and $48 \mathrm{~h}$ in the vehicle-treated group (Table 1). Two pulses of DHKF-2 $\alpha(194.6$ and $292.7 \mathrm{pg} / \mathrm{ml})$ were observed in 1 of 3 animals treated with oestrogen before slaughter at $24 \mathrm{~h}$. Otherwise the patterns for concentrations of DHKF- $2 \alpha$ were similar to those observed in Exp. 1. A pulsatile pattern was evident in all oestrogen-treated ewes before slaughter at 36 and 48 h which resulted in elevated mean concentrations of DHKF- $2 \alpha$ (Table 1). Episodes in the secretion of DHKF-2 $\alpha$ exceeding the $\cdot$ criteria selected for peaks were not observed in ewes that received arachis oil or in oestrogen-treated ewes that were killed at $12 \mathrm{~h}$ (Table 1).

When treated with arachis oil, uterine concentrations of oxytocin receptor were similar in animals killed on Days 9, 10 or 11 after oestrus (Fig. 3). The administration of oestrogen increased $(P<0.05)$ concentrations of oxytocin receptor in caruncular endometrium and myometrium at $12 \mathrm{~h}$, and receptor concentrations were 4-fold higher in these tissues than in intercaruncular endometrium at this time. At $24 \mathrm{~h}$ oxytocin receptor concentrations were raised $(P<0.05)$ in intercaruncular tissue from oestrogen-treated ewes relative to those given vehicle, and receptor concentrations 
in all 3 uterine tissues from oestrogen-treated animals were higher at 36 and $48 \mathrm{~h}(P<0.01)$ than in control animals.

Effects of oestrogen treatment with and without oxytocin on incorporation of $\left[{ }^{3} \mathrm{H}\right]$ inositol into phosphatidylinositol and inositol phosphates are shown in Table 2. Oestrogen treatment resulted in increased labelling of phosphatidylinositol, the maximum increase occurring after $48 \mathrm{~h}$. Oestrogen alone had no effect on labelling of inositol phosphates. Oxytocin had no effect on incorporation of

Table 1. Concentrations of progesterone and 13,14-dihydro-15keto prostaglandin $\mathrm{F}-2 \alpha$ (DHKF-2 $\alpha$ ) in plasma during 12 -h periods preceding slaughter of groups of 3 ewes treated with arachis oil (control) or oestradiol benzoate $(750 \mu \mathrm{g})$ at $12: 00 \mathrm{~h}$ on Days $9(0 \mathrm{~h})$ and $10(24 \mathrm{~h})$ after oestrus (Exp. 2)

\begin{tabular}{ccc}
\hline $\begin{array}{c}\text { Time } \\
\text { period } \\
\text { (h relative to } \\
12: 00 \text { h on Day } 9)\end{array}$ & $\begin{array}{c}\text { Progesterone } \\
(\mathrm{ng} / \mathrm{ml})\end{array}$ & $\begin{array}{c}\text { DHKF-2 } \alpha \\
(\mathrm{pg} / \mathrm{ml})\end{array}$ \\
\hline $\begin{array}{c}\text { Control } \\
-12 \text { to } 0 \mathrm{~h}\end{array}$ & $2 \cdot 93 \pm 0 \cdot 18$ & \\
12 to $24 \mathrm{~h}$ & $3 \cdot 26 \pm 0 \cdot 20$ & $60 \cdot 2 \pm 0 \cdot 1$ \\
36 to $48 \mathrm{~h}$ & $3 \cdot 75 \pm 0 \cdot 20$ & $61 \cdot 4 \pm 1 \cdot 1$ \\
0 Oestradiol & & $62 \cdot 5 \pm 2 \cdot 2$ \\
0 to $12 \mathrm{~h}$ & $3 \cdot 72 \pm 0 \cdot 19$ & \\
12 to $24 \mathrm{~h}$ & $3 \cdot 70 \pm 0 \cdot 15$ & $61 \cdot 0 \pm 1 \cdot 0$ \\
24 to $36 \mathrm{~h}$ & $2 \cdot 92 \pm 0 \cdot 18$ & $87 \cdot 4 \pm 10 \cdot 3 \dagger$ \\
36 to $48 \mathrm{~h}$ & $2 \cdot 24 \pm 0 \cdot 34^{*}$ & $198 \cdot 2 \pm 26 \cdot 0^{* *}$ \\
\hline
\end{tabular}

Values are means \pm s.e.m. $(n=27)$ for samples collected every $1.5 \mathrm{~h}$.

Effects of oestradiol: $\dagger P<0 \cdot 10 ;{ }^{*} P<0.05 ;{ }^{*} P<0.01$. Values for 0 to $12 \mathrm{~h}$ and 24 to $36 \mathrm{~h}$ groups were compared to means for the -12 to $0 \mathrm{~h}$ plus 12 to $24 \mathrm{~h}$ and 12 to $24 \mathrm{~h}$ plus 36 to $48 \mathrm{~h}$ groups respectively.

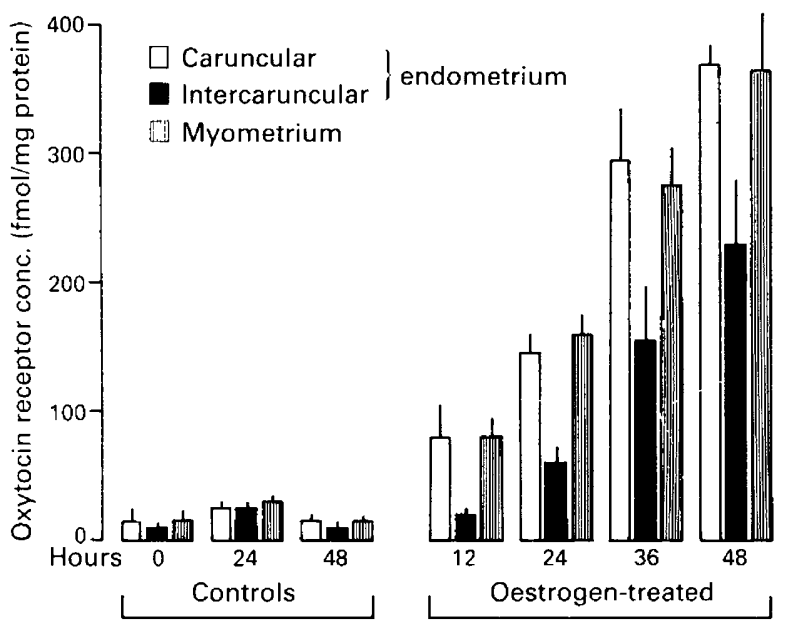

Fig. 3. Concentrations of oxytocin receptor measured in caruncular endometrium, intercaruncular endometrium and myometrium in ewes treated with oestradiol-17ß benzoate or arachis oil. Ewes receiving oestrogen were treated at 12:00 h on Days 9 and 10 after oestrus and were killed at 24:00 h on Day $9(12 \mathrm{~h}), 12: 00 \mathrm{~h}$ on Day $10(24 \mathrm{~h}), 24: 00 \mathrm{~h}$ on Day $10(36 \mathrm{~h})$ or 12:00 h on Day $11(48 \mathrm{~h})$. Control animals, which received arachis oil at $12: 00 \mathrm{~h}$ on Days 9 and 10 , were killed at 12:00 h on Day $10(24 \mathrm{~h})$ or 12:00 h on Day $11(48 \mathrm{~h})$; untreated animals were killed at 12:00 h on Day $9(0 \mathrm{~h})$. Values are means \pm s.e.m. for 3 ewes killed at each time. 
Table 2. Phosphoinositide turnover in slices of caruncular endometrium incubated with and without oxytocin $\left(10^{-7} \mathrm{M}\right.$ for $\left.20 \mathrm{~min}\right)$

\begin{tabular}{|c|c|c|c|c|c|}
\hline \multirow{2}{*}{$\begin{array}{l}\text { Time after } \\
\text { in-vivo } \\
\text { treatment } \\
\text { (h) }\end{array}$} & \multirow{2}{*}{$\begin{array}{l}\text { Addition } \\
\text { of oxytocin } \\
\text { in vitro } \\
(- \text { or }+)\end{array}$} & \multicolumn{4}{|c|}{$\begin{array}{c}10^{-3} \times \text { d.p.m./g wet wt incorporated } \\
\text { into: }\end{array}$} \\
\hline & & PI & IP & $\mathrm{IP}_{2}$ & $\mathrm{IP}_{3}$ \\
\hline \multicolumn{6}{|l|}{ Controls } \\
\hline gintiono & - & $\begin{array}{c}5 \cdot 7 \pm 0.2 \\
(1 \cdot 75 \pm 0.035)\end{array}$ & $\begin{array}{c}8.9 \pm 3.5 \\
(1.99 \pm 0.463)\end{array}$ & $\begin{array}{c}4.5 \pm 1.6 \\
(1.29 \pm 0.436)\end{array}$ & $\begin{array}{c}1.9 \pm 1 \cdot 0 \\
(0 \cdot 32 \pm 0.540)\end{array}$ \\
\hline 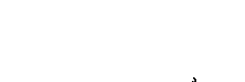 & + & $\begin{array}{c}5 \cdot 2 \pm 0 \cdot 5 \\
(1 \cdot 65 \pm 0 \cdot 101)\end{array}$ & $\begin{array}{c}2.9 \pm 0.4 \\
(1.04 \pm 0.138)\end{array}$ & $\begin{array}{c}2 \cdot 3 \pm 0 \cdot 3 \\
(0 \cdot 83 \pm 0 \cdot 137)\end{array}$ & $\begin{array}{c}1.0 \pm 0.3 \\
(-0.15 \pm 0.367)\end{array}$ \\
\hline \multirow[t]{2}{*}{24} & - & $\begin{array}{c}8 \cdot 2 \pm 1 \cdot 4 \\
(2 \cdot 09 \pm 0 \cdot 179)\end{array}$ & $\begin{array}{c}6.6 \pm 3.7 \\
(1.58 \pm 0.530)\end{array}$ & $\begin{array}{c}4 \cdot 0 \pm 2 \cdot 1 \\
(1 \cdot 12 \pm 0 \cdot 499)\end{array}$ & $\begin{array}{c}3 \cdot 6 \pm 2 \cdot 6 \\
(0 \cdot 71 \pm 0 \cdot 740)\end{array}$ \\
\hline & + & $\begin{array}{c}9 \cdot 1 \pm 1 \cdot 5 \\
(2 \cdot 18 \pm 0 \cdot 151)\end{array}$ & $\begin{array}{c}5 \cdot 0 \pm 0 \cdot 9 \\
(1 \cdot 58 \pm 0 \cdot 214)\end{array}$ & $\begin{array}{c}1 \cdot 9 \pm 0 \cdot 7 \\
(0 \cdot 54 \pm 0 \cdot 346)\end{array}$ & $\begin{array}{c}2 \cdot 4 \pm 0 \cdot 8 \\
(0.68 \pm 0 \cdot 500)\end{array}$ \\
\hline \multirow[t]{2}{*}{48} & - & $\begin{array}{l}13 \cdot 1 \pm 4 \cdot 1 \\
(2 \cdot 48 \pm 0 \cdot 294)\end{array}$ & $\begin{array}{l}20 \cdot 9 \pm 9 \cdot 6 \\
(2 \cdot 84 \pm 0 \cdot 434)\end{array}$ & $\begin{array}{l}13 \cdot 6 \pm 9 \cdot 6 \\
(2 \cdot 07 \pm 0 \cdot 726)\end{array}$ & $\begin{array}{c}8 \cdot 5 \pm 4 \cdot 7 \\
(1 \cdot 83 \pm 0 \cdot 559)\end{array}$ \\
\hline & + & $\begin{array}{c}9.0 \pm 0 \cdot 5 \\
(2 \cdot 19 \pm 0 \cdot 060)\end{array}$ & $\begin{array}{c}8 \cdot 2 \pm 0 \cdot 9 \\
(2 \cdot 09 \pm 0 \cdot 114)\end{array}$ & $\begin{array}{c}4 \cdot 7 \pm 0 \cdot 6 \\
(1 \cdot 53 \pm 0 \cdot 148)\end{array}$ & $\begin{array}{c}4 \cdot 7 \pm 1 \cdot 6 \\
(1 \cdot 44 \pm 0 \cdot 345)\end{array}$ \\
\hline \multirow{3}{*}{$\begin{array}{ll}\text { Oestradiol } & \\
& 12\end{array}$} & & & & & \\
\hline & - & $\begin{array}{c}13 \cdot 8 \pm 1 \cdot 8 \\
(2 \cdot 61 \pm 0 \cdot 143)\end{array}$ & $\begin{array}{c}5 \cdot 1 \pm 3.9 \\
(0.99 \pm 0.798)\end{array}$ & $\begin{array}{c}3 \cdot 3 \pm 2 \cdot 6 \\
(0 \cdot 41 \pm 0 \cdot 872)\end{array}$ & $\begin{array}{c}4 \cdot 7 \pm 4 \cdot 4 \\
(-0 \cdot 90 \pm 2 \cdot 086)\end{array}$ \\
\hline & + & $\begin{array}{c}13 \cdot 9 \pm 4 \cdot 3 \\
(2 \cdot 54 \pm 0 \cdot 313)\end{array}$ & $\begin{array}{c}5 \cdot 8 \pm 2 \cdot 3 \\
(1 \cdot 54 \pm 0 \cdot 515)\end{array}$ & $\begin{array}{c}3.6 \pm 1 \cdot 6 \\
(1.08 \pm 0.406)\end{array}$ & $\begin{array}{c}4 \cdot 7 \pm 3 \cdot 5 \\
(0.73 \pm 1 \cdot 011)\end{array}$ \\
\hline \multirow[t]{2}{*}{24} & - & $\begin{array}{c}9 \cdot 9 \pm 2 \cdot 1 \\
(2 \cdot 25 \pm 0 \cdot 204)\end{array}$ & $\begin{array}{c}6 \cdot 5 \pm 1 \cdot 3 \\
(1 \cdot 84 \pm 0 \cdot 197)\end{array}$ & $\begin{array}{c}2 \cdot 9 \pm 0.6 \\
(1 \cdot 00 \pm 0.257)\end{array}$ & $\begin{array}{c}1.9 \pm 0.8 \\
(0.46 \pm 0 \cdot 400)\end{array}$ \\
\hline & + & $\begin{array}{c}14 \cdot 8 \pm 3 \cdot 5 \\
(2 \cdot 64 \pm 0 \cdot 223)\end{array}$ & $\begin{array}{l}20 \cdot 7 \pm 7 \cdot 7 \\
(2 \cdot 85 \pm 0 \cdot 459)\end{array}$ & $\begin{array}{c}6.9 \pm 2 \cdot 3 \\
(1.76 \pm 0.464)\end{array}$ & $\begin{array}{c}5 \cdot 2 \pm 1 \cdot 9 \\
(1 \cdot 49 \pm 0 \cdot 405)\end{array}$ \\
\hline \multirow[t]{2}{*}{36} & - & $\begin{array}{c}24 \cdot 3 \pm 2.9 \\
(3 \cdot 18 \pm 0 \cdot 131)\end{array}$ & $\begin{array}{c}8 \cdot 2 \pm 1 \cdot 2 \\
(2 \cdot 08 \pm 0 \cdot 156)\end{array}$ & $\begin{array}{c}5.3 \pm 0.9 \\
(1.65 \pm 0 \cdot 156)\end{array}$ & $\begin{array}{c}5 \cdot 0 \pm 0 \cdot 7 \\
(1 \cdot 60 \pm 0 \cdot 132)\end{array}$ \\
\hline & + & $\begin{array}{c}38 \cdot 3 \pm 3 \cdot 1 \\
(3 \cdot 63 \pm 0 \cdot 134)\end{array}$ & $\begin{array}{c}48 \cdot 5 \pm 9 \cdot 1 \\
(3 \cdot 84 \pm 0 \cdot 214)\end{array}$ & $\begin{array}{c}25 \cdot 3 \pm 4 \cdot 2 \\
(3 \cdot 20 \pm 0 \cdot 176)\end{array}$ & $\begin{array}{c}18 \cdot 1 \pm 6 \cdot 4 \\
(2 \cdot 78 \pm 0 \cdot 326)\end{array}$ \\
\hline \multirow[t]{2}{*}{48} & - & $\begin{array}{c}41 \cdot 0 \pm 6 \cdot 1 \\
(3 \cdot 69 \pm 0 \cdot 144)\end{array}$ & $\begin{array}{c}7.2 \pm 0 \cdot 7 \\
(1.96 \pm 0 \cdot 120)\end{array}$ & $\begin{array}{c}3 \cdot 2 \pm 0 \cdot 5 \\
(1 \cdot 15 \pm 0 \cdot 156)\end{array}$ & $\begin{array}{c}0.9 \pm 0.1 \\
(-0.13 \pm 0.075)\end{array}$ \\
\hline & + & $\begin{array}{c}45 \cdot 2 \pm 8 \cdot 7 \\
(3 \cdot 77 \pm 0 \cdot 213)\end{array}$ & $\begin{array}{c}42.4 \pm 18.9 \\
(3.49 \pm 0.542)\end{array}$ & $\begin{array}{l}23.6 \pm 13.0 \\
(2.69 \pm 0.771)\end{array}$ & $\begin{array}{c}12 \cdot 7 \pm 7.5 \\
(1.91 \pm 0.938)\end{array}$ \\
\hline
\end{tabular}

Values are means \pm s.e.m. for incorporation of $\left[{ }^{3} \mathrm{H}\right]$ inositol into phosphatidylinositol (PI), inositol monophosphate (IP), inositol bisphosphate $\left(\mathrm{IP}_{2}\right)$ and inositol trisphosphate $\left(\mathrm{IP}_{3}\right)$. All incubations were in triplicate; $\mathrm{N}=3$ animals at each time.

Values in parentheses are $\log _{e}$ transformed; statistical analysis was by multivariable analysis of variance. 
$\left[{ }^{3} \mathrm{H}\right]$ inositol into either phosphatidylinositol or inositol phosphates in the absence of oestrogen $\left(\chi^{2}=0.43 ; P>0.1\right)$, but labelling of inositol phosphates was significantly enhanced by oxytocin in animals killed after treatment with oestrogen $\left(\chi^{2}=9.7 ; P<0.01\right)$.

\section{Discussion}

The experiments described here demonstrate that luteolysis induced by oestrogen is preceded by increases in uterine concentrations of the oxytocin receptor and by an increase in the ability of oxytocin to stimulate phosphoinositide turnover in vitro. These results, together with measurements of circulating hormone concentrations in a parallel experiment, indicate that the sequence of events after oestrogen administration was: (a) induction of oxytocin receptor (by $12 \mathrm{~h}$ ); (b) induction of the phosphoinositide response to oxytocin (by $24 \mathrm{~h}$ ); (c) the onset of episodic PGF-2 $\alpha$ secretion (at $35 \pm 3 \mathrm{~h}$ ); (d) functional luteolysis (beginning at $42 \pm 3 \mathrm{~h}$ ), and oestrus (at $67 \pm 9 \mathrm{~h}$ ). Episodes of PGF- $2 \alpha$ secretion (as indicated by circulating concentrations of DHKF-2 $\alpha$ ) were preceded by secretion of oxytocin (first observed $26 \pm 3 \mathrm{~h}$ after treatment) but this did not appear to be a response to oestrogen treatment since pulses of a comparable amplitude occurred in 3 of the 5 control ewes. A similar episodic release of oxytocin occurs during the mid-luteal phase of the oestrous cycle in cattle (Walters et al., 1984). The coincidence of episodes of secretion of PGF-2 $\alpha$ and oxytocin noted in treated ewes confirms observations made at spontaneous luteolysis (Fairclough et al., 1980; Flint \& Sheldrick, 1983). Uterine concentrations of the oxytocin receptor observed here $48 \mathrm{~h}$ after oestrogen treatment were similar to those reported previously at oestrus (Roberts et al., 1975; Sheldrick \& Flint, 1985) except that the increase in the myometrium was more pronounced in the present study. Phosphoinositide turnover parameters were comparable to those reported for ovariectomized ewes treated with progestagen and oestrogen (Flint et al., 1986).

These findings raise the question of whether the induction of oxytocin receptor is responsible for the luteolytic action of administered oestrogen. Evidence that the receptor may play a role in this process includes the fact that oestradiol treatment causes secretion of PGF- $2 \alpha$ (Fig. 1; Caldwell et al., 1972; Barcikowski et al., 1974; Ford et al., 1975) which is an established response of the endometrium to oxytocin (Sharma \& Fitzpatrick, 1974; Mitchell et al., 1975; Roberts et al., 1976); that immunization against oxytocin delays luteal regression (Sheldrick et al., 1980; Schams et al., 1983) and that uterine concentrations of the oxytocin receptor rise before spontaneous oestrus (Roberts et al., 1975; Sheldrick \& Flint, 1985). The present results show that receptor concentrations rise before any fall in the circulating concentration of progesterone in animals treated with oestrogen.

An increase in the responsiveness of the uterus to oxytocin, such as would be anticipated from the induction of the oxytocin receptor, may explain the enhanced sensitivity of the corpus luteum to PGF-2 $\alpha$ in animals given oestrogen (Hixon et al., 1975, 1983). Prostaglandin F-2 $\alpha$ and its analogues are known to release oxytocin from the corpus luteum in ewes (Flint \& Sheldrick, 1982; Heap et al., 1986); administered PGF-2 $\alpha$ may therefore stimulate production of additional endogenous PGF-2 $\alpha$, as a result of release of luteal oxytocin and its effect on the uterus, in animals with a raised uterine oxytocin receptor level.

The fact that induction of the oxytocin receptor preceded luteolysis in animals treated with oestrogen raises the possibility that the rise in receptor at the end of the oestrous cycle (Roberts et al., 1976) plays a causative role in spontaneous luteal regression. The interval between receptor induction and reduced progesterone observed here $(30 \mathrm{~h})$ is close to the sampling interval $(24 \mathrm{~h})$ used in earlier work, which could explain why it was not previously possible to dissociate these events (Sheldrick \& Flint, 1985). Gradual induction of the oxytocin receptor towards the end of the cycle may result from an increase in the sensitivity of the uterus to oestrogen (see McCracken et al., 1984). Evidence supporting this suggestion includes the prolongation of luteal function after destruction of ovarian follicles by X-irradiation in sheep and cattle (Karsch et al., 1970; Hixon 
et al., 1975; Villa-Godoy et al., 1985) and the failure to identify any significant rise in circulating oestrogen secretion preceding luteal regression (Roberts et al., 1975; Baird et al., 1976).

The mechanism by which oxytocin stimulates uterine prostaglandin synthesis has been suggested to involve increased hydrolysis of phosphatidylinositol phosphates with concomitant production of diacylglycerol, which is subsequently hydrolysed to release arachidonic acid (Flint et al., 1986). In the present work oestrogen treatment induced a marked increase in the ability of oxytocin to stimulate phosphoinositide turnover in vitro, which might be expected to result from an increase in oxytocin receptor concentration.

We thank Dr Eurof Walters and David Brown, A.F.R.C. Statistics Group, Cambridge and Linda Sheldrick, A.F.R.C., Babraham, for their assistance. This work was supported in part by the John E. Fogarty Senior International Fellowship Program of the U.S. Public Health Service and by a grant from the U.K. Agricultural and Food Research Council awarded jointly to A.P.F.F. and Professor G. E. Lamming, A. F. R. C. Research Group on Hormones and Farm Animal Reproduction, Sutton Bonington.

\section{References}

Baird, D. T., Land, R. B., Scaramuzzi, R. J. \& Wheeler, A. G. (1976) Endocrine changes associated with luteal regression in the ewe; the secretion of ovarian oestradiol, progesterone and androstenedione and uterine prostaglandin $F_{2 a}$ throughout the oestrous cycle. J. Endocr. 69, 275-286.

Barcikowski, B., Carlson, J. C., Wilson, L. \& McCracken, J. A. (1974) The effect of endogenous and exogenous estradiol- $17 \beta$ on the release of prostaglandin $\mathrm{F}_{2 a}$ from the ovine uterus. Endocrinology 95, 1340-1349.

Bolt, D. J. \& Hawk, H. W. (1975) Prevention of estrogen-induced regression of corpora lutea in ewes by hysterectomy. J. Anim. Sci. 40, 687-690.

Brunner, M. A., Donaldson, L. E. \& Hansel, W. (1969) Exogenous hormones and luteal function in hysterectomized and intact heifers. J. Dairy Sci. 52, 1849-1854.

Caldwell, B. V., Tillson, S. A., Brock, W. A. \& Speroff, L. (1972) The effects of exogenous progesterone and estradiol on prostaglandin $F$ levels in ovariectomized ewes. Prostaglandins 1, 217-228.

Downes, C. P. \& Michell, R. H. (1981) The polyphosphoinositide phosphodiesterase of erythrocyte membranes. Biochem. J. 198, 133-140.

Fairclough, R. J., Moore, L. G., McGowan, L. T., Petersen, A. J., Smith, J. F., Tervit, H. R. \& Watkins, W. B. (1980) Temporal relationships between plasma concentrations of 13,14-dihydro-15-keto-prostaglandin $\mathrm{F}$ and neurophysin I/II around luteolysis in sheep. Prostaglandins 20, 199-208.

Flint, A. P. F. \& Sheldrick, E. L. (1982) Ovarian secretion of oxytocin is stimulated by prostaglandin. Nature, Lond. 297, 587-588.

Flint, A. P. F. \& Sheldrick, E. L. (1983) Evidence for a systemic role for ovarian oxytocin in luteal regression in sheep. J. Reprod. Fert. 67, 215-222.

Flint, A. P. F., Leat, W. M. F., Sheldrick, E. L. \& Stewart, H. J. (1986) Stimulation of phosphoinositide hydrolysis by oxytocin and the mechanism by which oxytocin controls prostaglandin synthesis in the ovine endometrium. Biochem. J. 237, 797-805.

Ford, S. P., Weems, C. W., Pitts, R. E., Pexton, J. E., Butcher, R. L. \& Inskeep, E. K. (1975) Effects of estradiol- $17 \beta$ and progesterone on prostaglandins $F$ in sheep uteri and uterine venous plasma. J. Anim. Sci. 41, 1407-1413.

Gill, J. L. (1978) Design and Analysis of Experiments in the Animal and Medical Sciences, Vol. II, pp. 203-220. Iowa State University Press, Ames.

Hansel, W. \& Convey, E. M. (1983) Physiology of the estrous cycle. J. Anim. Sci. 57, Suppl. 2, 404424.

Heap, R. B., Fleet, I. R., Flint, A. P. F., Sheldrick, E. L. \& Goode, J. A. (1986) Ovarian oxytocin release after infusion of prostaglandin $F_{2 \alpha}$ into a uterine lymphatic or uterine vein in the sheep. J. Endocr. 108 (Suppl.). Abstr. 238.

Hixon, J. E., Gengenbach, D. R. \& Hansel, W. (1975) Failure of prostaglandin $F_{2 a}$ to cause luteal regression in ewes after destruction of ovarian follicles by $\mathrm{X}$-irradiation. Biol. Reprod. 13, 126-135.

Hixon, J. E., Pimentel, C. A., Weston, P. G., Chafetz, E. P., Shanks, R. D. \& Hansel, W. (1983) A luteolytic interaction between estradiol benzoate and prostaglandin $F_{2 a}$ in cattle. J. Anim. Sci. 56, 1190-1197.

Karsch, F. J., Noveroske, J. W., Roche, J. F., Norton, H. W. \& Nalbandov, A. V. (1970) Maintenance of ovine corpora lutea in the absence of ovarian follicles. Endocrinology 87, 1228-1236.

Krebs, H. A. \& Henseleit, K. (1932) Untersuchungen Über die Harnstoffbildung in Tierkörper. Z. phys. Chem. 210, 33-66.

Lerman, P. M. (1980) Fitting segmented regression models by grid search. Applied Statistics 29, 77-84.

McCracken, J. A., Schramm, W. \& Okulicz, W. C. (1984) Hormone receptor control of pulsatile secretion of $\mathrm{PGF}_{2 \mathrm{a}}$ from the ovine uterus during luteolysis and its abrogation in early pregnancy. Anim. Reprod. Sci. 7, $31-55$.

Merriam, G. R. \& Wachter, K. W. (1982) Algorithms for 
the study of episodic hormone secretion. Am. J. Physiol. 243, E310-E318.

Merriam, G. R., Kozuch, M. \& Wachter, K. W. (1983) Pulsar User's Guide, Version 1983/1. Developmental Endocrinology Branch, NICHHD, Bethesda, Maryland, U.S.A.

Mitchell, M. D., Flint, A. P. F. \& Turnbull, A. C. (1975) Stimulation by oxytocin of prostaglandin $\mathbf{F}$ levels in uterine venous effluent in pregnant and puerperal sheep. Prostaglandins 9, 47-56.

Nissenson, R., Flouret, G. \& Hechter, O. (1978) Opposing effects of estradiol and progesterone on oxytocin receptors in rabbit uterus. Proc. natn. Acad. Sci. U.S.A. 75, 2044-2048.

Richards, D. E., Irvine, R. F. \& Dawson, R. M. C. (1979) Hydrolysis of membrane phospholipids by phospholipases of rat liver lysosomes. Biochem. J. 182 , 599-606.

Roberts, J. S., Barcikowski, B., Wilson, L., Skarnes, R. C. \& McCracken, J. A. (1975) Hormonal and related factors affecting the release of prostaglandin $F_{2 \alpha}$ from the uterus. J. Steroid Biochem. 6, 1091-1097.

Roberts, J. S. McCracken, J. A., Gavagan, J. E. \& Soloff, M. S. (1976) Oxytocin-stimulated release of prostaglandin $\mathbf{F}_{2 \alpha}$ from ovine endometrium in vitro: correlation with estrous cycle and oxytocin-receptor binding. Endocrinology 99, 1107-1114.

Schams, D., Prokopp, A. \& Barth, D. (1983) The effect of active and passive immunization against oxytocin on ovarian cyclicity in ewes. Acta endocr., Copenh. 103, $337-344$.
Seldinger, S. I. (1953) Catheter replacement of the needle in percutaneous arteriography. Acta radiol. 39, $368-376$.

Sharma, S. C. \& Fitzpatrick, R. J. (1974) Effect of oestradiol $17 \boldsymbol{\beta}$ and oxytocin treatment on prostaglandin $F$ alpha release in the anoestrous ewe. Prostaglandins 6, 97-105.

Sheldrick, E. L. \& Flint, A. P. F. (1981) Circulating concentrations of oxytocin during the estrous cycle and early pregnancy in sheep. Prostaglandins 22, 631-636.

Sheldrick, E. L. \& Flint, A. P. F. (1985) Endocrine control of uterine oxytocin receptors in the ewe. $J$. Endocr. 106, 249-258.

Sheldrick, E. L., Mitchell, M. D. \& Flint, A. P. F. (1980) Delayed luteal regression in ewes immunized against oxytocin. J. Reprod. Fert. 59, 37-42.

Solof, M. S. (1975) Uterine receptor for oxytocin: effects of estrogen. Biochem. Biophys. Res. Commun. 65, 205-212.

Villa-Godoy, A., Ireland, J. J., Wortman, J. A., Ames, N. K., Hughes, T. L. \& Fogwell, R. L. (1985) Effect of ovarian follicles on luteal regression in heifers. $J$. Anim. Sci. 60, 519-527.

Walters, D. L., Schams, D. \& Schallenberger, E. (1984) Pulsatile secretion of gonadotrophins, ovarian steroids and ovarian oxytocin during the luteal phase of the oestrous cycle in the cow. J. Reprod. Fert. 71, 479-491. 